\title{
KEDUDUKAN TANAH MELAYU SEBAGAI NEGERI NAUNGAN DALAM EMPAYAR BRITISH BERDASARKAN SUMBER KOLONIAL
}

\section{(Malaya as a Protectorate of the British Empire Based on Colonial Sources)}

\author{
Mohd Shazwan Mokhtar \\ msm@ukm.edu.my \\ Mohd Samsudin \\ moss@ukm.edu.my
}

\section{Suffian Mansor \\ smansor@ukm.edu.my}

Pusat Kajian Sejarah, Politik dan Hal Ehwal Antarabangsa,

Fakulti Sains Sosial dan Kemanusiaan, Universiti Kebangsaan Malaysia.

Pengarang koresponden (Corresponding author): *

Sila rujuk: Mohd Shazwan Mokhtar, Mohd Samsudin \& Sufian Mansor. (2022). Kedudukan Tanah Melayu sebagai negeri naungan dalam empayar British Berdasarkan sumber kolonial. Melayu: Jurnal Antarabangsa Dunia Melayu, 15(1), 25-48. http:// doi.org. 10.37052/jm.15(1)no2

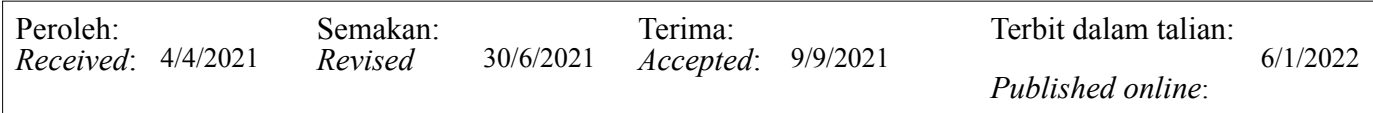

\begin{abstract}
Abstrak
Artikel ini bertujuan untuk menentukan kedudukan negeri naungan sebagai jajahan dalam empayar British. Isu negeri naungan menjadi polemik dalam kalangan sarjana bagi menentukan kedudukan Tanah Melayu ketika era penjajahan British. Berdasarkan tafsiran secara literal terhadap istilah negeri naungan, sesetengah pihak mendakwa Tanah Melayu tidak pernah dijajah. Namun begitu, apakah konsep atau
\end{abstract}


sistem sebenar negeri naungan menurut sudut pandang kolonial British? Kaedah kajian sejarah digunakan untuk mengumpul sumber primer daripada Arkib Negara Malaysia, Arkib Negara United Kingdom dan Perpustakaan Universiti Kebangsaan Malaysia. Dokumen Pejabat Tanah Jajahan siri CO 717, CO 273, CO 576 dan FCO 141 antara tahun 1920-an dan 1930-an merupakan sumber utama yang digunakan bagi menjawab persoalan kajian yang dinyatakan. Melalui sumber British tersebut, artikel ini memformulasikan kedudukan sebenar negeri naungan dan Tanah Melayu dalam empayar British. Hasil kajian mendapati, sebagai negeri naungan, Tanah Melayu merupakan jajahan dalam empayar British. Namun begitu, British hanya mempunyai bidang kuasa tertentu seperti yang termaktub dalam perjanjiannya dengan Raja-Raja Melayu. British hanya mengiktiraf kekebalan Raja-Raja Melayu daripada tindakan mahkamah, manakala daulat pentadbiran dan perundangan berada di bawah bidang kuasa kerajaan British melalui Pejabat Tanah Jajahan. Walaupun undang-undang imperial tidak terpakai secara langsung di Tanah Melayu, British menggunakan majlis perundangan untuk mengabsahkan pelaksanaannya.

Kata kunci: Sejarah Malaysia, imperialisme, kolonialisme, empayar kolonial, Durbar, desentralisasi

\begin{abstract}
This article aims to determine the protectorate as a dependent of the British empire. The issue of the protectorate has been polemic among scholars in determining the position of Malaya during the British colonial period. Based on the literal interpretation of the term "protectorate", some parties have claimed that Malaya was never colonised. However, what is the concept or real system of the protectorate from the British colonial perspective? Historical methodology was applied by collecting primary sources from the National Archives of Malaysia, the National Archives of United Kingdom and the National University of Malaysia Library. The Colonial Office's documents in series $C O$ 717, CO 273, CO 576 and FCO 141, which are between the 1920s and 1930s, were the main sources used to answer the research question. Using the British sources, this article formulated the exact position of the protectorate and Malaya in the British empire. The study found that, as a protectorate, Malaya was a dependent of the British empire. Nevertheless, the British possessed limited jurisdiction, as stipulated in the agreement with the Malay Rulers. The British only recognised the Malay Rulers' immunity from jurisdiction of the courts, while the administrative and legislative sovereignty was under the British government's jurisdiction through the Colonial Office. Although the imperial laws were not imposed directly in Malaya, the British used the legislative council to endorsed its implementation.
\end{abstract}

Keywords: Malaysian history, imperialism, colonialism, colonial empire, Durbar, decentralization 


\section{PENGENALAN}

Sejak akhir abad ke-19 hingga tamat Perang Dunia Pertama pemerintahan kerajaan British bersilih ganti antara Parti Liberal dan Parti Konservatif. Situasi ini turut mempengaruhi kedinamikan dasar imperial terhadap tanah jajahan. Namun begitu, peristiwa penting berlaku antara tahun 1870 hingga 1874, iaitu ketika pentadbiran Lord Kimberley John Wodehouse sebagai Setiausaha Tanah Jajahan. Desakan tokoh imperialis, iaitu Edward Knatchbull-Hugessen, Setiausaha Rendah Parlimen mendorong Lord Kimberley melaksanakan dasar campur tangan di negeri-negeri Melayu (McIntyre, 1967). Melalui dasar tersebut, British cuba menjadi kuasa imperial tunggal di Semenanjung Tanah Melayu dengan matlamat menguasai sumber bahan mentah untuk pelabuhan Negeri-Negeri Selat (NNS). Kepentingannya adalah untuk mengukuhkan kedudukan pelabuhan NNS sebagai pusat perdagangan antara Barat dengan China. Oleh itu, sistem Residen mula diperkenalkan sebagai alat kawalan politik British terhadap negeri-negeri Melayu (McIntyre, 1967). Melalui pentadbiran Residen, negeri-negeri Melayu mula menjadi negeri naungan dalam empayar British. Walaupun, kuasa Residen terbatas sebagai penasihat, perjanjian antara Raja-Raja Melayu dengan kerajaan British menetapkan bahawa raja atau sultan perlu meminta nasihat dan bertindak atas nasihat Residen untuk melaksanakan pemerintahan. Hal ini termasuklah dalam aspek politik dan ekonomi. Walau bagaimanapun, Residen tidak mempunyai bidang kuasa berkaitan dengan hal ehwal adat istiadat Melayu dan agama Islam, kerana kuasa bagi kedua-dua aspek tersebut merupakan bidang kuasa Raja-raja Melayu (Gullick, 1992).

Latar sejarah ini kemudiannya menjadi polemik yang mengatakan Tanah Melayu tidak pernah dijajah oleh British. ${ }^{1}$ Polemik tersebut bukanlah isu baharu, pertikaian Tanah Melayu sebagai bukan jajahan British atau bukan sebahagian daripada empayar British telah berlaku sejak sebelum merdeka lagi. Misalnya, pada tahun 1927, Jepun mempertikaikan kedudukan Tanah Melayu sebagai bukan sebahagian daripada empayar British, tetapi sebagai sebuah negara asing bagi Britain (CO 717/55/7, 1927). Selain itu, pada tahun 1931, Roland Braddell yang merupakan peguam bela dan peguam cara di NNS, Negeri-Negeri Melayu Bersekutu (NNMB) dan Johor cuba menjelaskan kedudukan Tanah Melayu sebagai negeri naungan dalam empayar British. Braddell (1931) berhujah negerinegeri Melayu merupakan negeri yang mempunyai separa kedaulatan dan institusi politik tempatannya kekal merdeka. Oleh itu, kerajaan British tidak mempunyai kuasa kedaulatan sepenuhnya terhadap negeri-negeri Melayu, khususnya NNMB dan Johor yang bertaraf negeri naungan. Bidang kuasa tersebut menjadikan negerinegeri Melayu bukan sebagai tanah jajahan dalam empayar British. Hujah tersebut 
turut digunakan dalam penulisan terkini yang mengklasifikasikan dua bentuk negeri naungan dalam empayar British berdasarkan Akta Bidang Kuasa Asing 1890 (Foreign Jurisdiction Act). Pertamanya, negeri naungan kolonial (Colonial Protectorate) yang merujuk jajahan British di Afrika, manakala keduanya, negeri naungan yang mengekalkan kedaulatan pemerintah tempatan (Ahmad Kamal Ariffin \& Nur Hannah, 2015). Sungguhpun begitu, kajian tersebut masih tidak dapat menjelaskan kedudukan sebenar Tanah Melayu sebagai negeri naungan dalam empayar British. Ironinya, pertikaian Jepun dan pandangan Braddell (1931) telah ditolak dan dikritik oleh pentadbir British di Tanah Melayu. Tambahan lagi, Kementerian Luar Negeri (Foreign Office) dan Pejabat Tanah Jajahan di London turut bekerjasama menjelaskan kedudukan Tanah Melayu sebagai negeri naungan British.

Berdasarkan masalah kajian tersebut, artikel ini menjelaskan kedudukan Tanah Melayu sebagai negeri naungan dalam empayar British. Tafsiran artikel ini adalah berdasarkan rekod kolonial daripada Pejabat Tanah Jajahan dan juga rekod kolonial tempatan yang disimpan di Arkib Negara. Proses tafsiran ini turut dibantu dengan menggunakan sumber sekunder. Oleh itu, tafsiran yang sehampir mungkin berkaitan dengan kedudukan sebenar negeri-negeri Melayu sebagai jajahan dalam empayar British dapat dirumuskan. Sifat bertumpu Eropah ini menyumbang kepada penjelasan sebenar negeri naungan yang ditubuhkan oleh British di negeri-negeri Melayu. Hasil kajian mendapati, negeri naungan merupakan sebahagian daripada jajahan dalam empayar British. Kerajaan British mempunyai kuasa kawalan langsung terhadap kedaulatan politik dan ekonomi seperti yang dipersetujui RajaRaja Melayu dalam siri perjanjian. Tambahan pula, NNMB merupakan model negeri naungan yang dikuasai British sepenuhnya oleh British melalui dominasi pegawai kolonial dan bidang kuasa Majlis Mesyuarat Persekutuan (MMP) yang ditubuhkan pada tahun 1909.

\section{NEGERI NAUNGAN SEBAGAI JAJAHAN BRITISH}

Pengkaji sejarah Barat mentafsirkan peluasan kuasa British sejak abad ke-19 dan abad ke-20 sebagai pembentukan empayar tidak formal atau informal empire (Hayman, 2018). Perkembangan empayar tidak formal ini dipengaruhi dasar perdagangan bebas British sejak tahun 1840-an yang membuka pasaran ekonomi baharu di Hindia Barat dan Asia. Pembukaan pasaran tersebut melibatkan dominasi eksport barangan British dan modal kewangan dari London ke wilayah yang kaya dengan sumber ekonomi. Sehingga tahun 1870-an, eksport modal British dianggarkan mencapai sehingga $£ 50$ 
juta. Dominasi ekonomi ini membolehkan golongan pemodal dan peniaga British menguasai aktiviti ekonomi di pasaran baharu tadi (James, 1994). Perkembangan ekonomi bebas ini secara tidak langsung membentuk penjajahan ekonomi atau imperialisme ekonomi British pada abad ke-19. Namun begitu, Gallagher \& Robinson (1953), mencabar tafsiran ini dengan alasan penguasaan ekonomi juga merupakan satu bentuk penjajahan langsung atau formal empire. Tambahan lagi, bukti sejarah telah membuktikan berlakunya proses penjajahan yang rancak pada akhir abad ke19, iaitu ketika zaman akhir pemerintahan Ratu Victoria. Perbezaan pandangan ini boleh dikaitkan dengan situasi di Britain pada tempoh tersebut yang menyaksikan berlakunya persaingan politik antara golongan imperialis dengan golongan antiimperialis. Walaupun, golongan anti-imperialis mendominasi pentadbiran kerajaan dengan dasar perdagangan bebas, kebergantungan Britain terhadap sumber bahan mentah tanah jajahan tetap wujud. Melalui kebebasan untuk melabur dan membuka peniagaan, golongan perdagangan bebas berharap eksport bekalan bahan mentah dan produk makanan dapat dimonopoli Britain. Kesannya, sektor pembuatan Britain dapat mendominasi pasaran dunia (Robinson, 2003). Dasar ini sebenarnya merupakan kesan pemulihan doktrin merkantilisme pada abad ke-19 yang dikenali sebagai neo-merkantilisme (Lihat Crowley, 1990).

Antara tahun 1850-an dan 1860-an, akhbar British menggunakan istilah imperialisme bagi menggambarkan kawalan politik oleh negara terhadap wilayah asing (Dmitriev, 2009). Umumnya, kawalan politik British terhadap wilayah asing bertujuan melindungi kepentingan ekonominya daripada masalah anarki, ancaman kuasa asing dan serangan lanun. Oleh sebab itu, pada awal abad ke-19, kawalan politik ini dilaksanakan melalui mekanisme perjanjian antara British, sama ada melalui syarikat atau pasukan tentera dengan pemerintah tempatan (James, 1994). Peranan kerajaan British, khususnya Pejabat Tanah Jajahan dalam pembentukan empayar agak terbatas. Dasar kerajaan untuk tidak menguasai tanah jajahan baharu yang dianggap akan menambahkan beban kewangan British. Namun begitu, kerajaan British tidak menolak sebarang bentuk campur tangan, melainkan kedudukan Tanah Jajahan Mahkotanya terancam (Hyam, 2002). Oleh sebab itu, Sir Harry Orb, Gabenor pertama NNS melakukan campur tangan di negeri-negeri Melayu tanpa kelulusan Pejabat Tanah Jajahan (McIntyre, 1967).

Walau bagaimanapun, menjelang akhir abad ke-19, kerajaan British mula beransur-ansur campur tangan dalam urusan politik dan ekonomi tanah jajahan. Peristiwa penguasaan British terhadap Mesir pada tahun 1884 merupakan titik berakhirnya era empayar tidak formal di Asia. Namun begitu, mekanisme perjanjian terus digunakan untuk membentuk jajahan baharu tetapi tidak mengikat 
sepenuhnya komitmen kerajaan British terhadapnya. Jajahan ini dikenali sebagai protectorates atau ditakrifkan sebagai negeri naungan (James, 1994 \& Pusat Rujukan Persuratan Melayu). Timbul perbahasan dalam kalangan sarjana berkaitan dengan perbezaan antara protectorates dan protected states. Emerson (1964) misalnya berpandangan tiada konsep jelas yang membezakan kedua-dua istilah tersebut. Tambahan lagi, dalam rekod pejabat tanah jajahan istilah protectorates sering digunakan untuk merujuk negeri-negeri Melayu dan pada kes tertentu istilah colonies turut digunakan. Misalnya perbincangan antara Perbendaharaan British dengan Pejabat Tanah Jajahan berkaitan dengan bantuan kewangan selepas Perang Dunia Pertama. Pihak Perbendaharaan menolak permintaan Pejabat Tanah Jajahan untuk memberikan bantuan kewangan kepada NNMB kerana berstatus protectorates (CO 717/25, 1922; T176/11, 1923). Tambahan lagi, pada tahun 1927 pihak editor The Chamber of Commerce Journal turut mengkategorikan NNMB dan Negeri-Negeri Melayu Tidak Bersekutu (NNMTB) sebagai koloni dalam senarai Crown Colonies and Protectorates bagi hubungan perdagangan antara empayar British (Sel Sec 3739, 1927).

Selain itu, selepas pemisahan pentadbiran Domion daripada pentadbiran Pejabat Tanah Jajahan pada tahun 1925, Crown Colonies and Protectorates mula dikenali sebagai empayar kolonial dalam empayar British. Empayar kolonial merupakan terma rujukan yang digunakan Pejabat Tanah Jajahan untuk merujuk jajahan British di kawasan beriklim tropika (CO 885/29/8, 1927). Ketika Persidangan Pejabat Tanah Jajahan pada tahun 1927, istilah colonies dan tropical colonies digunakan oleh pegawai kolonial untuk merujuk Crown Colonies and Protectorates (CO 885/29/8, 1927). Walau bagaimanapun, sebelum pembentukan NNMB melalui Perjanjian Persekutuan 1895, istilah yang digunakan oleh British ialah Protected Native States atau Protected Malay States (FCO 141/15783, 1893; Institut Terjemahan Negara, 2008). ${ }^{2}$ Justeru, bolehlah dihujahkan bahawa tafsiran terhadap istilah protectorates adalah tidak jelas atau tidak mempunyai jenis tertentu, tetapi bentuk naungannya boleh dibezakan melalui kaedah kawalan yang dilaksanakan British (Heatley, 1894; Innes, 1916).

Fieldhouse (1981) merumuskan ciri persamaan antara kedua-dua protectorates dan protected states ini sebagai tempat atau wilayah yang dianggap atau sukarela meminta atau menerima perlindungan daripada kuasa atau negara lain yang berjanji untuk mempertahankannya daripada ancaman kuasa atau negara ketiga. Namun begitu, dari sudut pandang kuasa imperial atau negara yang bertindak sebagai penaung, penguasaan terhadap negeri naungan adalah untuk mencapai objektif penjajahan tertentu tanpa komitmen atau tanpa kawalan sepenuhnya oleh kerajaan 
imperial. Oleh sebab itu, pembentukan negeri naungan British sering melibatkan siri perjanjian dengan pemerintah tempatan yang membataskan atau memperincikan bidang kuasa kerajaan imperial (Fieldhouse 1981). ${ }^{3}$ Berdasarkan tafsiran tersebut dan penelitian terhadap rekod Pejabat Tanah Jajahan, dapatlah dirumuskan bahawa pandangan yang mengatakan terdapat dua jenis negeri naungan dalam empayar British, iaitu Colonial Protectorate dan Protectorate boleh ditolak (Ahmad Kamal Ariffin \& Nur Hannah, 2015).

Menurut Lauterpacht (1959) sejarah penggunaan istilah Colonial Protectorate ialah sebagai terma rujukan terhadap negeri naungan yang dianggap sebagai bukan negara dalam undang-undang antarabangsa. Masalah ini dihadapi oleh British untuk mengabsahkan penjajahannya di Afrika sebagai negeri naungan. Berdasarkan Artikel 35, "the Final Act of the Berlin Africa Conference" atau Akta Persidangan Berlin 1885, pembentukan negeri naungan memerlukan persetujuan antara negara penaung dengan negara dinaungi. Oleh itu, British memperkenalkan Colonial Protectorate sebagai muslihat seperti kononnya kerajaan Colonial Protectorate bersetuju menyerahkan negaranya kepada British sebagai negeri naungan (Lauterpacht 1959). Di samping itu, penelitian terhadap rekod British turut menunjukkan penggunaan istilah negeri naungan berubah mengikut perubahan dasar imperial British. Oleh itu, sistem negeri naungan bagi sesebuah jajahan tidak boleh difahami berdasarkan satu model negara lain yang menerima perlindungan British. Alasannya, setiap negeri naungan mempunyai mekanisme perjanjian atau bentuk penyerahan kuasa yang berbeza. ${ }^{4}$

Berdasarkan perkembangan undang-undang antarabangsa, Lauterpacht, Hakim Mahkamah Keadilan Antarabangsa turut berhujah tentang pengenalan sistem negeri naungan atau protectorates dalam empayar British yang dikesan sejak tahun 1885, iaitu dengan penguatkuasaan Akta Persidangan Berlin. Persidangan ini merupakan kemuncak kepada pembahagian wilayah jajahan di Afrika dalam kalangan kuasakuasa Eropah seperti Britain, Jerman, Sepanyol dan Perancis. Artikel 34 akta tersebut memberikan kuasa kepada negara terlibat untuk menguasai sepenuhnya atau menubuhkan negeri naungan di wilayah dalam benua Afrika (Lauterpacht, 1959). Menurut Heatley (1894) akta ini merupakan sumber kuasa awal kuasakuasa Eropah untuk mengenakan bidang kuasanya terhadap wilayah jajahan atau mengawal negara asing melalui pengenalan sistem negeri naungan. Matlamat ini boleh dikaitkan kuasa Artikel 35 yang memberikan kuasa penguasaan daulat wilayah melalui penguatkuasaan bidang kuasa atau pemerintahan secara de facto. Oleh sebab itu, mekanisme perjanjian sering digunakan dalam pembentukan negeri naungan British (Lauterpacht, 1959). 


\section{PEMBENTUKAN KERAJAAN KOLONIAL}

Pada peringkat awal campur tangan British di Tanah Melayu, Majlis Mesyuarat Negeri (MMN) ditubuhkan pada peringkat negeri sebagai alat kawalan kolonial (Lennard, 1933). Majlis ini merupakan institusi perundangan pada peringkat negeri yang mengabsahkan pentadbiran Residen atau Penasihat British. Selain itu, pengenalan institusi MMN juga merupakan usaha British untuk mengawal penentangan golongan pembesar dengan melibatkan mereka dalam hal ehwal pentadbiran negeri (Chew, 1966). Situasi di NNMB membuktikan Residen lebih mendominasi urusan MMN berbanding dengan pembesar dan sultan. Sementara itu, situasi berbeza di NNMTB apabila British cuba mengawal bidang kuasa pembesar dan sultan melalui penasihatnya dalam MMN (Emerson, 1964). Secara keseluruhannya, dominasi pegawai British dalam MMN bersifat in loco regis, iaitu mempunyai kuasa autokratik dalam pemerintahan negeri (FCO 141/16583, 1926).

Hujah di atas boleh dikaitkan dengan proses penguasaan kerajaan negeri Perak oleh W. Jervois, Gabenor NNS pada tahun 1875. Proses penguasaan tersebut membuktikan eksploitasi British terhadap Perjanjian Pangkor 1874 untuk menentukan sultan bagi negeri Perak. Kesempatan untuk menjajah negeri Perak bermula apabila Jervois mempertikaikan keupayaan Sultan Abdullah bertindak sebagai pemerintah negeri Perak. Alasan digunakan, sultan dikatakan tidak mematuhi terma dalam Perjanjian Pangkor 1874. Seolah-olah cuba mengetepikan ketidakpuasan hati Sultan Abdullah berkaitan dengan perjanjian tersebut, Jervois mempertikaikan kewibawaan baginda yang mula hilang sokongan di wilayah hilir Perak (National Library Board Singapore, 2017). Jervois mengugut Sultan Abdullah dengan menyatakan:

We have already told our friend that the only way of settling the state affairs in Perak is for officers of the British Government to take charge of the country, assisted by a Malay Council. Now we proposed to our friend that officers of the British Government shall govern the country in the name of our friend. If our friend agrees to this, our friend will still be recognised as Sultan and receive a large allowance, but, if our friend does not agree to this, we cannot help our friend, and our friend will be no longer Sultan (National Library Board Singapore, 2017).

Di sebalik ugutan tersebut, Jervois telah mempunyai perancangan untuk menggantikan Sultan Abdullah dengan Raja Muda Yusuf sebagai Sultan Perak 
sekiranya Sultan Abdullah dianggap tidak layak lagi sebagai pemerintah oleh British (National Library Board Singapore, 2017). Namun begitu, pada masa yang sama J.W.W Birch, Residen Perak telah merangka Proklamasi Sultan Perak untuk memberikan kuasa perundangan kepada Residen sebagai Hakim untuk menjatuhkan hukuman atas semua kes jenayah. Dalam satu lagi proklamasi, Birch meminta Sultan Perak untuk menyerahkan kuasa menggumpulkan dan membelanjakan hasil pendapatan negeri. Namun begitu, Sultan Abdullah menolak untuk menandatangani kedua-dua proklamasi tersebut (National Library Board Singapore, 2017). Penolakan Sultan Abdullah tersebut boleh dikaitkan dengan bantahan baginda untuk menyerahkan negeri Perak kepada Ratu England melalui proklamasi yang disediakan oleh Birch. Namun begitu, Residen British tersebut mengugut Sultan Abdullah, bahawa baginda akan digantikan dengan Raja Yusof sekiranya baginda tidak bersetuju untuk menandatanganinya. Kesannya, atas nasihat Syahbandar, akhirnya Sultan Abdullah menurunkan cop mohor dan tandatangan baginda (Abdullah Zakaria, 1997). Proklamasi Sultan Abdullah 1875 yang disediakan oleh Birch merupakan satu bentuk mekanisme imperial yang diwujudkan bagi mendapatkan kuasa pemerintahan dan kedaulatan pentadbiran negeri Perak untuk British. Proses ini berlaku secara paksaan dengan menggunakan isu pengiktirafan sebagai sultan berdasarkan Perjanjian Pangkor 1874. Penyerahan kuasa ini diratifikasikan Gabenor NNS melalui satu proklamasi bertarikh 15 Oktober 1875. Proklamasi yang kemudiannya disebarkan di negeri Perak, menyatakan Perak berada dalam masalah anarki dan membahayakan kepentingan British. Pemerintah Perak dikatakan tidak mampu mematuhi terma Perjanjian Pangkor 1874. Oleh itu, Kerajaan British mengambil keputusan untuk mentadbir negeri Perak atas nama sultan melalui pelantikan Pesuruhjaya dan Pembantu Pesuruhjaya baginda Ratu untuk menjalankan pentadbiran kerajaan (National Library Board Singapore, 2017). Sarjana berpandangan, proses penjajahan British di Perak ini kemudiannya menjadi model yang digunakan dalam proses penjajahan di negeri-negeri Melayu yang lain (Andaya \& Andaya, 2017; Hyam, 2002; Harper, 1999).

Pada tahun 1893, British mula mempertimbangkan untuk membentuk pentadbiran persekutuan antara negeri Perak, Selangor, Pahang dan Negeri Sembilan. Kepentingan pentadbiran persekutuan ini adalah untuk menyelesaikan masalah pentadbiran yang tidak seragam dan keperluan untuk membentuk kerjasama ekonomi antara negeri-negeri tersebut (FCO 141/15783, 1893). Dasar ini dilaksanakan ketika pentadbiran Joseph Chamberlain selaku Setiausaha Tanah Jajahan. Pentadbiran Chamberlain dikatakan cenderung untuk campur tangan dalam hal ehwal tanah jajahan, khususnya kerjasama ekonomi yang dapat 
menguntungkan British (Constantine, 1984). Oleh itu, setelah mendapat arahan daripada Chamberlain, Frank Swettenham yang kemudiannya dilantik sebagai Residen Jeneral pertama bagi NNMB, mula mendapatkan persetujuan sultan dan pembesar keempat-empat negeri tersebut untuk membentuk persekutuan NNMB melalui Perjanjian Persekutuan 1895 (FCO 141/15783, 1893).

Perjanjian Persekutuan 1895 yang membawa kepada pembentukan NNMB merupakan perjanjian yang absahkan kedudukan persekutuan sebagai negeri naungan British. Namun begitu, menurut J.R. Innes (1916), Pesuruhjaya Kehakiman NNMB, perjanjian tersebut tidak bertujuan untuk mendefinisikan batas bidang kuasa British melainkan berkaitan dengan agama Islam. Ciri ini membezakan sistem negeri naungan di Tanah Melayu dengan sistem negeri naungan British di Afrika, apabila titah perkenan Raja England menjadi asas pentadbiran British seperti yang termaktub dalam Foreign Jurisdiction Act. Namun begitu, tidak bermakna akta sama tidak memberikan Raja England bidang kuasa terhadap NNMB. Berdasarkan analisis Lennard (1933), yang juga pernah menjadi Hakim Mahkamah Agung di NNS, NNMB dan Johor, Foreign Jurisdiction Act turut memberikan kuasa kepada Raja England untuk menggubal undang-undang untuk semua negeri naungan. Namun begitu, bagi kes Tanah Melayu, hal ini terbatas pada bidang kuasa perjanjian bagi negeri tertentu. Beliau turut menambah, berbanding Residen British yang merupakan wakil kerajaan British di NNMB, penasihat British di NNMTB ialah kakitangan di bawah pemerintahan Sultan dalam Majlis Mesyuarat Negeri. Sultan bagi NNMTB tetap terikat dengan terma perjanjian yang mengkehendaki nasihat British dipatuhi. Kemuncak kepada pembentukan kerajaan kolonial di Tanah Melayu adalah melalui perasmian pembentukan NNMB pada tahun 1896. Namun begitu, Perjanjian Persekutuan 1895 tidak memberikan British kuasa untuk membentuk sebuah kerajaan persekutuan yang rasmi, tetapi pemusatan pentadbiran oleh Residen Jeneral di bawah bidang kuasa Pesuruhjaya Tinggi British. Oleh sebab itu, British memperkenalkan persidangan Durbar bagi NNMB pada tahun 1897. Durbar merupakan institusi asing dalam sistem pemerintahan Raja Melayu. British memperkenalkan Durbar sebagai strategi pengabsahan pembentukan kerajaan kolonial NNMB (Harper, 1999). Hujahan ini dibuktikan melalui pengisytiharan telegram Raja-Raja Melayu kepada Ratu Victoria yang menyatakan:

We, the Sultans of the Malay States of Selangor, Perak, Pahang and Negri Sembilan ... are met together for the first time in history to discuss the affairs of our States confederated under Your Majesty's gracious protection ... (CO 717/103, 1934). 
Persidangan Durbar turut mengiktiraf kedudukan Raja-Raja Melayu sebagai pemerintah berdaulat melalui adat istiadat diraja. Keberangkatan baginda ke persidangan Durbar didahului dengan upacara hormat diraja dan tembakan meriam. Namun begitu, persidangan Durbar tidak boleh dibuka tanpa ucapan pengisytiharan pembukaan oleh Pesuruhjaya Tinggi British, malah aturan mesyuarat dan usul mesyuarat dikawal oleh Residen Jeneral. Melalui kuasa kawalan tersebut, British menggunakan Durbar untuk mendapatkan persetujuan Raja-Raja Melayu bagi melaksanakan dasar yang melibatkan kerjasama antara negeri-negeri. Misalnya, pembangunan landasan kereta api dan jalan raya, urusan pinjaman wang antara negeri, pentadbiran tanah dan hal ehwal buruh (CO 717/103, 1934). Tambahan lagi, British turut menggunakan persidangan Durbar sebagai alat untuk mengawal pentadbiran hal ehwal Melayu dan Islam. Hal ini kerana Raja-Raja Melayu dan pembesar diberikan kebebasan untuk membahaskan kedua-dua isu tersebut. Namun begitu, resolusi atau cadangan yang diutarakan dalam persidangan Durbar tidak menjadi undang-undang, melainkan Raja-Raja Melayu bersetuju untuk melaksanakannya pada peringkat negeri masing-masing (CO 717/103, 1934).

Pada tahun 1909, British menguasai kedaulatan undang-undang NNMB melalui Perjanjian Pembentukan MMP (Innes, 1916). Melalui MMP, British dapat menyeragamkan undang-undang kolonial yang diabsahkan dengan menggunakan nama Raja-Raja Melayu (Ahmad Kamal Ariffin \& Suffian, 2014). Perjanjian tersebut membolehkan British menubuhkan badan perundangan tertinggi bagi NNMB dan memusatkan kuasa perintah tetapnya kepada Pesuruhjaya Tinggi British selaku Presiden Majlis (CAB 24/239/CP/81, 1932). Bidang kuasa Presiden Majlis melibatkan kawalan terhadap anggaran perbelanjaan dan pendapatan serta hal ehwal kewangan NNMB (CO 717/85, 1931). Kesannya, kuasa Residen pada peringkat negeri mula terhakis, MMN tidak mempunyai autonomi dan Raja-Raja Melayu menjadi ahli MMP tanpa kuasa veto (FCO 141/16583, 1926; Ahmad Kamal Ariffin \& Suffian, 2014). Pentadbiran undang-undang NNMB sebenarnya dikawal oleh Raja England melalui wakil baginda, iaitu Pesuruhjaya Tinggi British (CO 717/85, 1931). Pesuruhjaya Tinggi British turut mempunyai kawalan terhadap NNMTB, iaitu melalui penasihat British. Pada tahun 1931, rekod perbincangan Pejabat Tanah Jajahan, menjelaskan perbezaan sistem kolonial antara NNMB dengan NNMTB, iaitu pegawai British di NNMB lebih bersifat pemerintah de facto. Namun begitu, Pegawai British di NNMTB berperanan sebagai penasihat. Berdasarkan ketetapan tersebut, dapatlah disimpulkan bahawa sultan di NNMB tidak mempunyai kuasa eksekutif untuk memerintah, tetapi sultan di NNMTB mempunyai kuasa eksekutif dalam kerajaan negeri yang dikawal oleh Penasihat British (CO 717/81, 1931a). 
Pembentukan kerajaan kolonial di Tanah Melayu menjadikan, Pesuruhjaya Tinggi British sebagai pegawai tertinggi dalam pentadbiran di NNMB. Dalam hierarki pentadbiran kolonial pula, hanya Pesuruhjaya Tinggi British yang mempunyai kuasa untuk menghubungi atau merujuk Setiausaha Tanah Jajahan (Mohd Shazwan, 2019). Bidang kuasa ini turut terpakai di NNMTB apabila kerajaan British telah memberikan kuasa kepada beliau untuk bertindak sendiri atas semua hal ehwal Tanah Melayu yang mempunyai kepentingan kepada British. Sungguhpun begitu, tindakan Pesuruhjaya Tinggi British tetap tertakluk di bawah arahan Setiausaha Tanah Jajahan (CO 717/85, 1931).

\section{Kedudukan Raja-Raja Melayu}

Pengekalan institusi raja di Tanah Melayu ketika era penjajahan British ditafsirkan sebagai strategi British untuk mengukuhkan kuasa kawalannya tanpa penentangan daripada Raja-Raja Melayu. Strategi ini merupakan eksploitasi terhadap konsep kedaulatan raja dalam masyarakat Melayu(Smith, 1995). Dalam teks Sejarah Melayu, kedaulatan negara boleh dipindahkan kepada seorang raja melalui suatu persetujuan atau persefahaman yang disebut sebagai "waad" (Zainal, 2019). Pandangan ini dapat dikaitkan dengan tafsiran, Freund (1899), seorang sarjana undang-undang dari Amerika Syarikat yang menyatakan pada peringkat antarabangsa negeri naungan hilang kemerdekaannya. Alasannya, bidang kuasa penuh telah diberikan kepada negara pelindung atau negara penaung. Oleh itu, negeri naungan tidak mempunyai kuasa untuk menjalankan hubungan diplomatik atau menerima konsular tanpa melalui negara pelindung sebagai mediator.

Pengiktirafan British terhadap Raja-Raja Melayu sebagai Pengerusi dalam MMN boleh dikaitkan dengan konsep daulat sistem pemerintahan tradisi Melayu yang melibatkan kuasa pemerintahan negeri oleh raja (Jelani, 2019). Konsep ini mempunyai kaitan dengan penghakiman Prichard, J., Presiden Mahkamah di Tanah Melayu terhadap kes berkaitan dengan Sultan Pahang. Beliau berhujah, sebelum Perjanjian Persekutuan 1895, Perjanjian Pembentukan MMP 1909 dan Perjanjian Penstrukturan Semula MMP 1927, Sultan Pahang merupakan pemerintah berdaulat mutlak yang merupakan sumber kuasa eksekutif dan perundangan negeri. Oleh itu, baginda memerintah dengan mengeluarkan titah (CO 717/91, 1932). Namun begitu, W.S. Gibson, Penasihat Undang-Undang NNMB mendapati setelah pembentukan MMN, tiada lagi titah yang dikeluarkan oleh Sultan Pahang. Hal ini demikian kerana, proses penggubalan undang-undang dalam persidangan MMN dikanunkan tanpa pengetahuan dan persetujuan baginda (CO 717/91, 1932). 
Dalam penghakiman Mudie, J. pula menjelaskan persetujuan Raja-Raja Melayu dalam Perjanjian Pembentukan MMP 1909 dan Perjanjian Penstrukturan Semula MMP 1927 secara rasminya menyerahkan kuasa perundangan baginda kepada MMP, tetapi raja-raja tetap mempunyai bidang kuasa perundangan pada peringkat negeri. Merumuskan penghakiman tersebut beliau berhujah, sejak tahun 1909, Raja-Raja Melayu bagi NNMB ialah pemerintah constitutional sovereigns (CO 717/91, 1932). Menjelang tahun 1920-an, Raja-Raja Melayu bagi NNMB mula mengkritik pentadbiran terpusat oleh British melalui MMP. Desakan pengagihan kuasa mula diutarakan kepada Pejabat Tanah Jajahan (FCO 141/16583, 1926). Kesannya, pada tahun 1927, Perjanjian Penstrukturan Semula MMP dimeterai bagi menyerahkan semula kuasa dan autonomi Raja-Raja Melayu dalam MMN. Namun begitu, matlamat sebenar persetujuan British ini adalah untuk meredakan bantahan Raja-Raja Melayu NNMB terhadap pentadbiran persekutuan dan cuba meyakinkan Raja-Raja Melayu NNMTB untuk menyertai sebuah persekutuan baharu (CO 717/81, 1931a). Tambahan lagi, dalam proses pengagihan kuasa pentadbiran NNMB, British hanya menyerahkan kuasa pentadbiran bersifat bakian (residuary), sementara kuasa perundangan dan pentadbiran ekonomi tetap terpusat di MMP (CO 717/81, 1931a). Pemusatan tersebut merupakan usaha British untuk membentuk persekutuan baharu yang dikenali sebagai Malayan Union atau pan-Malayan Federation. Melalui dasar ini, British cuba menyatukan pentadbiran kolonial di Tanah Melayu ke tangan Pesuruhjaya Tinggi British yang juga merupakan Gabenor NNS (CO 717/88, 1931). Kedudukan Raja-Raja Melayu signifikan untuk mengabsahkan pembentukan Malayan Union pada tahun 1930-an. Oleh sebab, status negeri-negeri Melayu sebagai negeri naungan, British memerlukan persetujuan Raja-Raja Melayu untuk menyerahkan bidang kuasa berkaitan dengan Malayan Union melalui perjanjian (CO 717/81, 1931a). Bidang kuasa yang dimaksudkan ialah pemusatan pentadbiran kolonial antara negeri di bawah pentadbiran Pesuruhjaya Tinggi British. Pemusatan tersebut dilakukan melalui penubuhan Malayan Department. Pemusatan pentadbiran kolonial ini memberikan kuasa kepada kerajaan British untuk melantik pegawai Eropah bagi perkhidmatan kerajaan di seluruh Tanah Melayu (FCO 141/16337, 1935). Rancangan pembentukan Malayan Union ini turut melibatkan pemusatan pentadbiran kastam antara NNMB dengan NNMTB dan NNS. Pemusatan ini dilaksanakan melalui pembentukan Kesatuan Kastam yang memberikan kuasa kepada British untuk mengawal aktiviti pelabuhan dan pentadbiran kastam antara negeri-negeri (FCO 141/16337, 1935). Selain itu, British turut melakukan pemusatan pentadbiran pos di Tanah Melayu melalui penubuhan Lembaga Pos 
Tanah Melayu. Melalui pemusatan ini, sistem setem antara NNMB dan NNS dimansuhkan melalui pengenalan sistem setem tunggal untuk Tanah Melayu (FCO 141/16337, 1935).

British cuba mendapatkan persetujuan Raja-Raja Melayu untuk memusatkan pentadbiran kolonial, pos dan kastam melalui Persidangan Durbar di Singapura pada 11 Oktober 1930. Persidangan ini merupakan kejayaan British melibatkan Raja-Raja Melayu bagi NNMTB untuk terlibat dalam persidangan Durbar yang sebelum ini hanya untuk NNMB. Namun begitu, persidangan ini tidak berjaya mendapatkan persetujuan daripada semua Raja-Raja Melayu. Misalnya, Tengku Ibrahim, Pemangku Sultan Kedah mempersoalkan penggunaan istilah "Malaya" bagi jabatan pentadbiran kerajaan di Kedah yang ingin disatukan, kerana pada hemat baginda hal ini bertentangan dengan Perjanjian 1923. Selain itu, Sultan Sulaiman Badrul Alam Shah, pemerintah dari negeri Terengganu mempersoalkan matlamat yang terselindung melalui pemusatan pentadbiran yang dicadangkan, manakala Sultan Ismail, pemerintah negeri Kelantan meminta masa agar baginda dapat membincangkan hal tersebut dalam MMN (FCO 141/16337, 1935). Menurut Emerson (1964), Raja-Raja Melayu bagi NNMTB bimbang dengan usul Persidangan Durbar 1930 yang dianggap bakal menghakis bidang kuasa dan menghapuskan kedaulatan sultan pada peringkat negeri.

Keputusan Persidangan Durbar 1930 dibincangkan oleh pegawai kolonial dalam Persidangan Pejabat Tanah Jahahan pada 15 Mei 1931. Melalui persidangan tersebut British mula memberikan perhatian terhadap dasar desentralisasi di NNMB bagi meyakinkan Raja-Raja bagi NNMTB terhadap pemusatan pentadbiran yang ingin dilaksanakan. Dasar yang dimaksudkan ialah menurunkan kuasa autonomi kepada MMN di NNMB. Oleh itu, Pesuruhjaya Tinggi British diarahkan untuk pulang ke Tanah Melayu bagi meyakinkan Raja-Raja Melayu, bahawa usaha pembentukan Malayan Union melalui pemusatan pentadbiran kolonial tidak menghakis autonomi raja-raja dalam MMN (CO 717/81, 1931a). Pesuruhjaya Tinggi British berjaya mendapatkan persetujuan Raja-Raja Melayu bagi NNMB untuk melaksanakan dasar Malayan Union dalam Persidangan Durbar pada 19 Ogos 1931 di Sri Menanti. Persetujuan ini berdasarkan jaminan British mengembalikan kedudukan Raja-Raja Melayu dalam MMN dan pemerintah NNMB mempunyai kedudukan yang setara sama seperti Raja-Raja Melayu bagi NNMTB dalam MMN (FCO 141/16337, 1935). Ketika membentangkan cadangan pemusatan pentadbiran tersebut, Pesuruhjaya Tinggi British turut meyakinkan Raja-Raja Melayu bahawa dasar tersebut dapat meningkatkan hasil pendapatan negeri (CO 576/42, 1931). Walau bagaimanapun, Persidangan Pejabat Tanah 
Jajahan pada 7 Disember 1931 tidak meluluskan pelaksanaan dasar Malayan Union oleh Pesuruhjaya Tinggi British kerana isu pengagihan kuasa antara MMP dan MMN di NNMB tidak diselesaikan. Malah, keputusan untuk melaksanakan dasar tersebut perlu dibentangkan dalam Parlimen British dan diluluskan kabinet (CO 717/81, 1931b). Kesannya, Pejabat Tanah Jajahan campur tangan secara langsung dalam menentukan pengagihan kuasa di NNMB. Melalui Laporan Wilson 1931, British telah menurunkan kuasa pentadbiran kewangan bagi jabatan perkhidmatan persekutuan kepada MMN (CAB 24/239/CP/81, 1932). Antaranya termasuklah elaun dan pencen golongan pemerintah, pertanian, pendidikan dan pentadbiran kewangan untuk kastam, pos dan Malayan Establishment Office pada peringkat negeri (FMS, 1933). Dasar Malayan Union ini kemudiannya diluluskan Parlimen British pada 14 Julai 1933 (The Singapore Free Press and Mercantile Advertiser, 1933a). Pesuruhjaya Tinggi British kemudiannya menganjurkan Persidangan Durbar pada tahun 1934 yang turut melibatkan Raja-Raja Melayu dari NNMTB. Melalui persidangan ini, British cuba mendapatkan persetujuan NNMTB untuk terlibat dalam pembentukan Malayan Establishment Office, Kesatuan Kastam dan menyertai Lembaga Pos Tanah Melayu (FCO 141/16337, 1935). Walaupun tidak dinyatakan dengan jelas persetujuan NNMTB dalam Durbar, pada akhir tahun 1933, kerajaan NNMB telah meminda enakmen berkaitan dengan pejabat pos yang membenarkan penggunaan setem dari NNS dan NNMTB di NNMB (The Singapore Free Press and Mercantile Advertiser, 1933b). Pada tahun yang sama juga NNMTB bersetuju untuk terlibat dalam pembentukan Malayan Establishment Office yang kemudiannya dirasmikan pada tahun 1934. Persetujuan tersebut turut melibatkan komitmen NNMTB untuk menanggung liabiliti perkhidmatan Malayan Establishment Office pada peringkat negeri yang dibayar kepada Penbendaharaan Kolonial di NNS (Malaya Tribune, 1933). Namun begitu, Kesatuan Kastam antara NNMB dengan NNMTB dan NNS tidak berjaya dilaksanakan kerana mendapat tentangan daripada komuniti komersial, khususnya ahli-ahli tidak rasmi dalam Majlis Perundangan NNS (Emerson, 1964). Dasar ini hanya dilaksanakan pada peringkat NNMB, yang kemudiannya menyebabkan pedagang-pedagang British di NNS terpaksa membayar cukai import untuk memasarkan barangan mereka di NNMB (FCO 141/16337, 1935; CO 717/83, 1931; FMS, 1937).

\section{BIDANG KUASA BRITISH DI NEGERI-NEGERI MELAYU}

Mekanisme perjanjian digunakan British bagi melaksanakan bidang kuasa imperial dan kawalan kolonial di Asia Tenggara. ${ }^{5}$ Menurut Stockwell (1999), 
golongan pemerintah di rantau ini turut menggunakan mekanisme tersebut untuk mengekalkan kedudukan mereka di samping matlamat British yang ingin menguasai sumber ekonomi tempatan. Oleh sebab itu, pengukuhan kuasa imperial British di Semenanjung Tanah Melayu adalah melalui pegawai kolonial yang bertindak sebagai ejen dan penasihat yang bertindak sebagai eksekutif dalam kerajaan negerinegeri Melayu. Namun begitu, perbezaan dan perkembangan siri perjanjian antara British dengan Raja-Raja Melayu telah mewujudkan tiga unit politik kolonial di Tanah Melayu. Pertamanya, NNMB yang dibentuk antara negeri Perak, Selangor, Pahang dan Negeri Sembilan melalui Perjanjian 1895. Melalui perjanjian tersebut kuasa pentadbiran persekutuan dipusatkan di bawah pentadbiran Residen Jeneral yang merupakan ejen dan wakil kerajaan British. Kedua, NNMTB, iaitu istilah rujukan yang digunakan untuk negeri Kedah, Perlis, Terengganu, Kelantan dan Johor. Kelima-lima negeri ini tidak disatukan pentadbirannya pada peringkat persekutuan. Namun begitu, ejen dan wakil kerajaan British tetap dilantik yang dikenali sebagai Penasihat British bagi negeri Kelantan dan Kedah, Pegawai British yang berupa Pegawai Konsul di Terengganu, manakala Ketua Penasihat di Johor. Ketiga ialah NNS sebagai Tanah Jajahan Mahkota yang terdiri daripada Pulau Pinang, Singapura dan Melaka (CO 717/55, 1927; Institut Terjemahan Negara, 2008). Berbanding, NNMB yang dianggap mirip seperti NNS, kedudukan NNMTB bersifat "independent native states under British suzerainty". Sungguhpun begitu, NNMB dan NNMTB tetap diiktiraf sebagai negeri naungan (CO 273/539, 1927). Oleh sebab itu, sama seperti kedudukan Residen dan Residen Jeneral di NNMB, ejen dan wakil kerajaan British di NNMTB juga berada di bawah bidang kuasa Pesuruhjaya Tinggi British yang merupakan puncak pentadbiran kolonial di Tanah Melayu (CO 717/88, 1932).

Dalam penelitian Sadka (1968) terhadap perkembangan Sistem Residen di Perak, Selangor, Negeri Sembilan dan Pahang sebelum tahun 1895 mendapati bidang kuasa Pejabat Tanah Jajahan tidak mempunyai asas undang-undang. Residen hanya berperanan sebagai penasihat dan pengurus bagi pengumpulan hasil pendapatan dan pentadbiran umum negeri. Tambahan pula, kerajaan British tidak mempunyai bidang kuasa terhadap negeri. Kesamaran terhadap isu ini boleh dikaitkan dengan tiada akta yang menentukan bidang kuasa kerajaan British di wilayah asing pada tempoh tersebut, kerana Foreign Jurisdiction Act hanya diluluskan Parlimen British pada tahun 1890. Sadka (1968) turut menggunakan alasan hanya melalui akta tersebut Pejabat Tanah Jajahan mempunyai kuasa kawalan formal terhadap negeri naungan kolonial seperti bidang kuasanya terhadap Tanah Jajahan Mahkota. Namun begitu, menurut Heatley (1894), Foreign Jurisdiction Act hanya bersifat konsolidasi, malah, Perkara 1 akta tersebut mengabsahkan bidang kuasa kerajaan 
British sedia ada terhadap wilayah asing sama ada melalui penyerahan atau penguasaan (The National Archives, 2021). Bidang kuasa tersebut boleh dikaitkan dengan terma yang menetapkan Raja-Raja Melayu perlu meminta dan mengikuti nasihat pegawai British kecuali berkaitan dengan hal ehwal Melayu dan agama Islam (Smith, 1995). Berdasarkan terma tersebut, pada tahun 1932 Pejabat Tanah Jajahan bersetuju dengan penghakiman Hakim Mudie J. dalam mahkamah rayuan bahawa kedaulatan politik Raja-Raja Melayu terhadap pemerintahan negeri telah diserahkan kepada kerajaan British, namun kedaulatan Raja-Raja Melayu yang kebal daripada tindakan undang-undang kekal diiktiraf (CO 717/91, 1932). Oleh sebab itu, Raja-Raja Melayu dikatakan bersetuju untuk membentuk NNMB kerana Perjanjian Persekutuan 1895 tidak mengubah status kedudukan raja pada peringkat negeri (FCO 141/16583, 1926). Namun begitu, sebelum tahun 1896, pentadbiran kehakiman di negeri-negeri Melayu tidak seragam kerana Residen mempunyai kuasa terhadap kes rayuan, sementara Sultan mempunyai kuasa rayuan akhir. Setelah pembentukan NNMB, kedua-dua bidang kuasa ini dihapuskan dan digantikan dengan bidang kuasa Pesuruhjaya Kehakiman yang mempunyai kuasa terhadap mahkamah rayuan (Mallal, 1959).

Antara tahun 1920-an hingga 1930-an, kedudukan negeri-negeri Melayu dalam empayar British menghadapi pertikaian sama ada dari negara luar, syarikat swasta serta kalangan pegawai British di London sendiri. Terdapat beberapa faktor yang mendorong kepada pertikaian tersebut. Pertama, usaha pemusatan kuasa oleh Pesuruhjaya Tinggi British di Singapura melalui dasar desentralisasi NNMB pada pertengahan tahun 1920-an (Lihat Yeo, 1981). Kedua, campur tangan kerajaan dalam aktiviti ekonomi, khususnya sekatan bahan mentah (CO 717/91, 1932). Ketiga usaha pembentukan Malayan Union pada tahun 1930-an dan yang keempat, bantahan pelaksanaan dasar ekonomi imperial (Lihat Braddell, 1931; Kratoska, 2000). Secara keseluruhannya, pertikaian tersebut cuba menafikan kedudukan negeri-negeri Melayu sebagai sebuah negara asing dan bukan sebahagian daripada empayar British. Tambahan lagi, kesamaran bidang kuasa kerajaan British terhadap negeri-negeri Melayu menimbulkan perselisihan antara pegawai kolonial di Tanah Melayu yang menginginkan autonomi daripada Pejabat Tanah Jajahan. Hakikatnya, pada tahun 1923, Laurence Guillemard menjelaskan, kerajaan British mempunyai kuasa kawalan terhadap NNMB melalui Pejabat Tanah Jajahan. Bidang kuasa tersebut adalah setara dengan kawalan Pejabat Tanah Jajahan terhadap NNS, cuma bentuk kawalan di NNMB lebih longgar kerana setiap arahan dan dasar dari London perlu diabsahkan melalui majlis perundangan tempatan. Dalam kes NNMB, majlis perundangan yang dimaksudkan ialah MMP (FMS, 1923; FCO 141/16196, 
1914). Oleh itu, dapatlah dirumuskan bahawa kawalan British terhadap jajahan atau wilayah penguasaannya bersifat fleksibel. Terdapat sebahagian jajahan yang dikawal langsung oleh kerajaan British dan ada juga wilayah, terutamanya negeri naungan, dikawal kerajaan British melalui kawalan terhadap pemerintah tempatan (Johnson, 2003).

Pada tahun 1919, Parlimen British meluluskan Seksyen 5, Akta Kewangan berkaitan definisi empayar British. Seksyen tersebut menyatakan empayar British sebagai “... any of His Majesty's Dominions outside Great Britain and Ireland, and any territories under His Majesty's protection, and includes India". Definisi tersebut merupakan pengiktirafan dan pengabsahan kedudukan negeri naungan sebagai sebahagian daripada empayar British oleh Parlimen British (CO 717/55/7, 1927). Alasan perundangan ini digunakan oleh H.W. Malkin, Penasihat UndangUndang Kedua, Kementerian Luar Negeri British untuk mengiktiraf kedudukan negeri-negeri Melayu sebagai sebahagian daripada empayar British. Menurut Malkin, sebagai negeri naungan, negeri-negeri Melayu tidak mempunyai kuasa diplomatik pada peringkat antarabangsa. Tambahan lagi, pentadbiran kolonial di negeri-negeri Melayu berdasarkan sistem pentadbiran kolonial di Tanah Jajahan Mahkota. Oleh itu, sekiranya Britain menghadapi peperangan, negerinegeri Melayu tidak dianggap sebagai negara neutral dan boleh diserang oleh musuh British (CO 717/55/7, 1927). Pandangan ini turut disokong Cecil Hurts, Penasihat Undang-Undang Kementerian Luar Negeri British yang berhujah pada peringkat antarabangsa tiada jajahan yang menjadi negara asing antara satu sama lain. Walaupun terdapat penghakiman bahawa kes mahkamah seperti kes Duff Development melawan kerajaan Kelantan yang mengiktiraf kedaulatan sultan, kes tersebut tidak menafikan kedudukan negeri-negeri Melayu sebagai sebahagian daripada empayar British. Oleh itu, pada peringkat hubungan antarabangsa kerajaan Raja England mempunyai kuasa untuk menentukan hubungan diplomatik negerinegeri Melayu bagi pihak sultan atau raja (CO 717/55/7, 1927).

Dalam kes yang lain, pandangan kedua-dua pegawai Kementerian Luar Negeri British tersebut, boleh dikaitkan dengan persetujuan Raja-Raja Melayu bagi NNMB dalam mesyuarat MMP pada tahun 1914 yang menyatakan taat setia kepada baginda Raja England dan menyerahkan kuasa darurat kepada Pesuruhjaya Tinggi British. Penyerahan kuasa ini diabsahkan melalui penguatkuasaan enakmen "To Vest in the High Commissioner Exceptional Power in Times of Public Emergency" yang menyerahkan kuasa diktator kepada Pesuruhjaya Tinggi British (FMS, 1914). Walau bagaimanapun, tindakan tersebut merupakan arahan daripada kerajaan British bagi membolehkan NNMB dianggap sebagai sekutu British ketika era Perang Dunia 
Pertama (FCO 141/16196, 1914). Berdasarkan keseluruhan perbincangan tersebut, Leo Amery, Setiausaha Tanah Jajahan membuat keputusan kedudukan NNMB dan NNMTB bukanlah negara asing bagi Britain, tetapi merupakan negeri naungan dalam empayar British (CO 717/55/7, 1927).

\section{KESIMPULAN}

Dalam konteks perkembangan empayar British, negeri naungan merupakan salah satu jajahan dalam empayar British. Kedudukan tersebut telah disahkan melalui definisi empayar British dalam Akta Kewangan 1919. Namun begitu, bidang kuasa negeri naungan tidak mempunyai satu perintah tetap yang khusus bagi setiap wilayah yang dikuasai British. Walau bagaimanapun, Akta Persidangan Berlin 1885 dapat dijadikan sumber rujukan oleh pengkaji bagi mengesan akar umbi pengenalan sistem negeri naungan dalam perkembangan imperialisme Eropah. Berdasarkan akta ini kuasa-kuasa Eropah bersetuju pembentukan negeri naungan hendaklah melibatkan dua buah negara, iaitu negara yang menyerahkan bidang kuasa wilayahnya kepada satu lagi negara yang menjadi penaungnya. Proses penyerahan ini biasanya dilakukan melalui perjanjian antara kedua-dua belah pihak. Ketetapan ini boleh dikaitkan dengan tindakan negara penjajah mengekalkan institusi raja atau institusi kerajaan tempatan di negara yang dijadikan naungannya. Kemudian, bidang kuasa British di wilayah asing ini diperkukuh melalui Foreign Jurisdiction Act 1890. Oleh sebab itu, artikel ini berhujah, kedudukan negeri naungan dalam empayar British tidak boleh ditafsir secara literal dan sistemnya berbeza mengikut mekanisme perjanjian atau bentuk penyerahan kuasa yang dilakukan.

Tafsiran penjajahan British terhadap negeri-negeri Melayu juga tidak wajar difahami dengan mengambil kira kes atau peristiwa tertentu dalam lipatan sejarah. Tambahan pula, perubahan pemerintahan kerajaan British antara Parti Konservatif dan Parti Buruh turut mempengaruhi perubahan dasar penjajahan dan paradigma Pejabat Tanah Jajahan terhadap negeri naungan. Oleh sebab itu, artikel ini berhujah proses penjajahan British di Tanah Melayu berevolusi sejak akhir abad ke-19 hinggalah menjelang era penyahjajahan pada abad ke-20. Pengukuhan kuasa berlaku setiap kali kepentingan British terancam atau wujudnya arahan langsung daripada kerajaan British untuk dilaksanakan di Tanah Melayu. Antara bukti awal yang dibincangkan dalam artikel ini ialah tindakan Gabenor NNS terhadap Sultan Abdullah antara tahun 1874 hingga 1875. Kemudian, dasar campur tangan Pejabat Tanah Jajahan pada akhir abad ke-19, khususnya ketika pentadbiran Joseph Chamberlain yang meluluskan pembentukan NNMB pada tahun 1895. Pada tahun 
1909 pula, British memperkenalkan MMP bagi membolehkan undang-undang atau dasar dari London diabsahkan pelaksanaannya di NNMB. Pada tahun yang sama, British mula menguasai negeri-negeri Melayu utara melalui Perjanjian Anglo-Siam. Kes peluasan kuasa berbeza di negeri-negeri Melayu utara kerana tumpuan British adalah untuk menyekat kemaraan kuasa Eropah, khususnya Jerman di utara Tanah Melayu. Bahkan, British tidak mempunyai kebergantungan yang kuat terhadap ekonomi negeri-negeri Melayu utara, melainkan untuk membantu negeri-negeri tersebut mendapatkan bantuan kewangan dari NNMB dan melindungi kepentingan komersialnya (CO 717/25, 1922; CO 717/81, 1931b). Walau bagaimanapun, pandangan pihak kolonial terhadap negeri-negeri Melayu utara pada tahun 1920an dan 1930-an ini boleh dinilai semula.

Artikel ini turut merungkai persoalan, adakah Raja-Raja Melayu benar-benar berdaulat seperti yang digambarkan dalam teks sastera Melayu? Menurut Zainal (2019), tidak wujud kedaulatan tanpa negara dan penguasaan sendiri merupakan elemen penting yang menyatakan kebebasan sebuah negara yang mempunyai kuasa atau daulat. Dalam menjelaskan konsep tersebut, beliau turut menambah kedaulatan raja bersifat mutlak dan tidak berbelah bagi, iaitu tiada kuasa yang lebih tinggi atau kuat daripadanya di dalam sebuah negara. Namun begitu, berdasarkan rekod-rekod British, kuasa mutlak Raja-Raja Melayu telah dihadkan berdasarkan penyerahan kuasa dalam perjanjian. Hujah dominan dalam kalangan pegawai British di London ialah kedaulatan Raja-Raja Melayu hanya terbatas terhadap kekebalan daripada bidang kuasa mahkamah. Tambahan lagi, terdapat penghakiman mahkamah yang mengesahkan berlakunya penyerahan daulat politik atau pemerintahan oleh RajaRaja Melayu kepada kerajaan British, kecuali hal ehwal agama Islam dan Melayu (CO 717/91, 1932). Berdasarkan keseluruhan pembuktian sumber kolonial, artikel ini mentafsirkan negeri-negeri Melayu merupakan jajahan berstatus negeri naungan dalam empayar British.

\section{NOTA}

1. Abdul Rahim Sabri, Zainal Kling: Malaya tak pernah terjajah, Malaysiakini, 9 September 2011. Tanah Melayu Tidak Pernah Dijajah Sepenuhnya, mStar, 25 Februari 2012. Mohamad Hafiz Yusoff Bakri, "Ini besar punya putar"- Rais Yatim, Utusan Malaysia, 8 Februari 2021.

2. Pusat Rujukan dan Persuratan Melayu mendefinisikan British Protectorates sebagai negeri naungan British, manakala Protected States sebagai tanah naungan.

3. Menurut definisi yang dikeluarkan Arkib Negara United Kingdom, Protectorate ialah "A colony or territory 'protected' by a stronger state or empire. In effect, the protectorate must deal with 
the outside world solely via the protecting power. Can be a relationship aimed at leading to eventual independence, or of economic exploitation. Often used as an informal way to expand an empire".

4. Lihat perbincangan Hyam (2002), hlm. 119-133.

5. Lihat Institut Terjemahan Negara, Perjanjian \& Dokumen Lama Malaysia 1791-1965, ITNM, 2008 .

\section{RUJUKAN}

Abdul Rahim Sabri. (2011) Zainal Kling: Malaya tak pernah terjajah. Malaysiakini, 9 September. Diakses dari https://www.malaysiakini.com/news/175301.

Abdullah Zakaria Ghazali. (1997). Pasir Salak: Pusat gerakan menentang British di Perak. Yayasan Perak.

Ahmad Kamal Ariffin Mohd Rus \& Nur Hannah Ahmad Zainy. (2015). Status Negeri-Negeri Melayu Pada Era Pentadbiran British. Dlm. Ahmad Kamal Ariffin Mohd Rus \& Noor Ain Mat Noor (Eds.), Dasar dan tadbir dalam sejarah (39-68). Penerbit Universiti Malaya.

Ahmad Kamal Ariffin Mohd Rus \& Suffian Mansor. (2014). Pengukuhan Penguasaan British di Negeri-Negeri Melayu Bersekutu: Analisis Dua Perjanjian Majlis Mesyuarat Persekutuan, 1909 dan 1927. Dlm. Suffian Mansor, Sivachandralingam Sundara Raja, Arba'iyah Mohd. Noor \& (Eds.). Dasar dan tadbir dalam sejarah. Penerbit Universiti Malaya.

Ahmad Kamal Ariffin Mohd. Rus (pnyt.). Sejarah dan kesarjanaan (1-22). Jabatan Sejarah Universiti Malaya.

Andaya, B.W. \& Andaya, L.Y. (2017.) A history of Malaysia (3rd Ed.) Palgrave.

Braddell, Ronald. (1931). The legal status of the Malay States. The Malaya Publishing House Limited.

Chew, Ernest. (1966). The First State Council in the Protected Malay States.

Constantine, Stephen. (1984). The making of British Colonial Development Policy, 19141940. Frank Cass.

CAB 24/239/CP/81. (1932). Report of Brigadier-General Samuel Wilson, Permanent UnderSecretary of State for the Colonies on his Visit to Malaya 1932.

CO 273/539. (1927). British Imperialism in Malaya. 15

CO 576/42. (1931). Federated Malay States. Proceedings of Durbar held at Sri Menanti on Tuesday, 18th August, 1931, at 10. a.m.

CO 717/103. (1934). Federated Malay States. Proceedings of the Durbars held in 1897, 1903 and 1927. 
MELAYU: JURNAL ANTARABANGSA DUNIA MELAYU JILID 15 BIL. 1 JANUARI 2022

CO 717/25. (1922). Financial Position.

CO 717/55. (1927). The "S.S. and F.M.S." Fallacy by Sir George Maxwell.

CO 717/55/7. (1927). Imperial Preference.

CO 717/81. (1931a). Proposed Constitutional Changes in Malaya.

CO 717/81. (1931b). Devolution in the FMS.

CO 717/83. (1931). Proposed Tariff Changes in F.M.S.

CO 717/85. (1931). High Commissioner as President of the Federal Council.

CO 717/88. (1931). Decentralization and wider Federation.

CO 717/88. (1932). Devolution in the FMS.

CO 717/91. (1932). Legal Status of the Malay States.

CO 885/29/8. (1927). Colonial Office Conference, 1927. Appendices to the Summary of Proceedings.

Crowley, John E. (1990). Neo-Mercantilism and the wealth of nations: British comercial, policy after the American Revolution. The Historical Journal, 33(2).

Dewan Bahasa dan Pustaka. (2021). Pusat Rujukan Persuratan Melayu. Diakses dari https:// prpm.dbp.gov.my

Dmitriew, Sviatoslav. (2009). The Rise and Quick Fall of the Theory of Ancient Economic Imperialism. The Economic History Review, 62(4).

Emerson, Rupert. (1964). Malaysia: A study in direct and indirect rule. University of Malay Press.

FCO 141/15783. (1893). Singapore: Future administration of the Protected Native States; Treaty of Federation, 1895.

FCO 141/16196. (1914). Singapore: Placing Federated Malay States of War.

FCO 141/16337. (1935). Singapore: Federated Malay States. Proceedings of Durbar held from $1930-1935$.

FCO 141/16583. (1926). Observation Upon the Constitution of the Federated Malay States with General Reference to the Policy of Decentralisation, and the Appointment of the Chief Secretary to Government, and with Particular Reference to His Excellency the High Commissioner Memorandum, Federal Council Paper No. 39 of 1925.

Federated Malay States (FMS). (1914) Shorthand report of the Proceedings of the Federal Council, 11 August.

FMS. (1923). Shorthand Report of the Proceedings of the Federal Council, 11 July.

FMS. (1933). Shorthand Report of the Proceedings of the Federal Council, 31 June. 
FMS. (1937). Shorthand Report of the Proceedings of the Federal Council, 26 June. Malaya Tribune. (1933). The Wilson Report, 30 October.

Freund, Ernst. (1899). The control of dependencies through protectorates. Political Science Quarterly, 14(1).

Freund, Ernst. (1899). The control of dependencies through protectorates. Political Sciences Quarterly, 14(1).

Gallagher, John \& Robinson, Ronald. (1953). The imperialism of free trade. The Economic History Review, VI(1).

Gullick, J.M. (1992). Rulers and residents influence and power in the Malay states 18701920. Oxford University Press.

Harper, T.N. (1999). The end of empire and the making of Malaya. Cambridge University Press. 16

Hayman, Mark. (2018). Economic protectorate in Britain's informal empire: The trucial coast during the Second World War. The Journal of Imperial and Commonwealth History, 46(2).

Heatley, D.P. (1894). British protectorates and jurisdiction. Scottish Geographical Magazine, 10(9).

Hyam, Ronald. (2002). Britain's imperial century, 1815-1914 (3rd Ed.). Hampshire: Palgrave Macmillan.

Innes, J.R. (1916). Some notes on the constitution and legislation of the Federated Malay States. Journal of the Society of Comparative Legislation, 16(1).

Innes, J.R. (1916). Some Notes on the constitution and legislation of the Federated Malay States. Journal of the Society of Comparative Legislation, 16(1).

Institut Terjemahan Negara. (2008). Perjanjian \& dokumen lama Malaysia 1791-1965. ITNM.

James, Laurence. (1994). The rise and fall of the British Empire. St. Martin's Griffin.

Jelani Harun. (2019). Pengenalan. Dlm. Jelani Harun \& Rogayah A. Hamid (Eds.). Kedaulatan dan kekuasaan Melayu dalam teks sastera (xiii-xxv). Dewan Bahasa dan Pustaka.

Johnson, Robert. (2003). British imperialism. Palgrave Macmillan.

Kratoska, Paul H. (2000). Imperial unity versus local autonomy: British Malaya and the depression of the 1930s. Dlm. Boomgaard, Peter \& Brown, Ian (eds.). Weathering the strom (271-294). Institute of Southeast Asian Studies.

Lauterpacht, H. (1959). Chapter XVIII International Law and Colonial Question, 18701914. Dlm. Benians, E.A., Butler, J.R.M., Mansergh, P.N.S. \& Walker, E.A. (eds.). 
MELAYU: JURNAL ANTARABANGSA DUNIA MELAYU JILID 15 BIL. 1 JANUARI 2022

The Cambridge History of the British Empire: Vol. III The Empire-Commonwealth 1870-1919 (66-710). Cambridge: Cambridge University Press.

Lennard, Fiennes Barrett. (1933). Some aspects of colonial law. Transactions of the Grotius Society, 19.

Mallal, B.A. (1959). Law and law reporting in Malaya. University of Malaya Law Review 1(1).

McIntyre, W.D. (1967). The imperial frontier in the tropics 1865-75. Macmillan.

Mohamad Hafiz Yusoff Bakri. (2021). "Ini besar punya putar"- Rais Yatim. Utusan Malaysia, 8 Februari. Diakses di https://www.utusan.com.my/nasional/2021/02/ini-besar-punyaputar-rais-yatim/

Mohd Shazwan Mokhtar. (2019). Agenda imperialis dalam krisis pentadbiran kolonial di Negeri-Negeri Melayu Bersekutu. Jebat: Malaysian Journal of History, Politics \& Strategic Studies, 46(2).

National Library Board Singapore. (2017). Enquiry as to Complicity of Chiefs in the Perak Outrages. Precis of Evidence, 1876. Singapore: Straits Settlements Government. Diakses dari https://eresources.nlb.gov.sg/printheritage/detail/6894d568-6610-44c395ad-087562172369.aspx

Sadka, Emily. (1968). The Protected Malay States 1874-1895. University Malaya Press.

Sel Sec 3739/1927. (1927). Article for British Malaya in the Special Inter-Imperial Trade number of the Chamber of Commerce Journal.

Smith, Simon C. (1995). British relations with the Malay Rulers from decentralization to Malayan Independence 1930-1957. Oxford University Press.

T 176/11. (1923). Empire Development: Imperial Economic Conference. 17 The Singapore Free Press and Mercantile Advertiser. (1933a). Decentralisation in Malaya, 7 August.

Tanah Melayu Tidak Pernah Dijajah Sepenuhnya. (2012). mStar, 25 Februari. Diakses dari https:/www.mstar.com.my/lokal/semasa/2012/02/25/tanah-melayu-tidak-pernahdijajah-sepenuhnya

The National Archives. (2021). Foreign Jurisdiction Act 1890. Diakses dari https://www. legislation.gov.uk/ukpga/Vict/53-54/37/contents

The National Archives. (2021). Glossary - P. Diakses dari https://www.nationalarchives. gov.uk/cabinetpapers/help/glossary-p.htm\#Protectorate The Singapore Free Press and Mercantile Advertiser. (1933b). New State Stamps, 8 November.

Yeo, Kim Wah. (1981). The Guillemard-Maxwell power struggle, 1921-1925. Journal of the Malaysian Branch of the Royal Asiatic Society, 54(1).

Zainal Kling. (2019). Kedaulatan dan kekuasaan Melayu dalam teks sastera. Dlm. Jelani Harun \& Rogayah A. Hamid (Eds.), Kedaulatan dan kekuasaan Melayu dalam teks sastera (1-37). Dewan Bahasa dan Pustaka. 